\title{
A Mixed Review of the Adoption of Building Information Modelling (BIM) for Sustainability
}

\author{
Heap-Yih Chong ${ }^{1}$, Xiangyu Wang ${ }^{1}$, Cen-Ying Lee ${ }^{1, *}$ \\ ${ }^{1}$ School of Built Environment, Curtin University, Australia \\ * cenying.lee@postgrad.curtin.edu.au
}

\begin{abstract}
Building Information Modelling (BIM) is a digitalised technology under a collaborative working platform. Certain aspects of sustainability have been highlighted in recent BIM studies; however, no prior in-depth review has focused on BIM standards or guidelines and its uses for sustainability. This paper provides a mixed review to determine the current stateof-the-art BIM development for sustainability. A systematic review approach was adopted to analyse two main sources of literature, namely, BIM standards and guidelines; and peerreviewed academic publications. The result reveals that although there has been a significant amount of research and development about the use of BIM during various project phases, little work has been conducted about how it could be applied in refurbishment and demolition. Certain significant insights and implications have been uncovered, namely: (a) new BIM tools are required for assessing sustainability criteria; (b) the need for improved interoperability among BIM software and energy simulation tools; (c) BIM uses into various aspects of refurbishment and demolition have to be streamlined; and (d) an innovative procurement system is needed to adapt social sustainability into the project.
\end{abstract}


Keywords Literature Review, Sustainability, Sustainable Development, Building Information Modelling, Standards, Guidelines

\subsection{Introduction}

Building Information Modelling (BIM) has received enormous attention from both academia and industry (Eastman et al., 2011). BIM not only brings technical benefits to the development process, but delivers an innovative and integrated working platform to improve productivity and sustainability throughout the project life cycle (Elmualim and Gilder, 2014). To contribute to the sustainability, three essential elements, namely, social, economic, and environmental, often become metrics to measure the level of sustainability irrespective of fields (Khan et al., 2016).

Social sustainability refers to the ability of people to continue to live in a way that suits their needs and the needs of subsequent generations (Eastaway, 2012). The outcomes of social sustainability in a built environment are best achieved by taking into consideration the satisfaction of its stakeholders' needs (Almahmoud and Doloi, 2015). BIM can improve social sustainability in two main areas. First, BIM provides a better facility design for a society's comfort of living. BIM enables owners to review the design and give feedback through the visualization of a three-dimensional (3D) building information model before the facility is constructed. Second, BIM transforms conventional practice, which is often highly fragmented, to a better collaborative effort that strengthens the working relationship among project participants. In a BIM platform, team members have to share their own viewpoints of information with other members to form a reliable basis of decision making to construct a facility (NIBS, 2015). Subsequently, economical sustainability is a little more challenging to 
quantify as there is little data that identify where the green economy is developing (Gibbs and O’Neill, 2014). However, it is proven that BIM improves the life-cycle cost saving of a built facility. Lu et al. (2014) concluded that a cost saving of $6.92 \%\left(490.86 \mathrm{HKD} / \mathrm{m}^{2}\right)$ was achieved via cost benefit analysis conducted in a sample BIM project. Guo and Wei (2016), on the other hand, utilized BIM with an energy-simulation system to conduct an energy-consumption analysis that provided more comprehensive information for optimal design selection. Environmental sustainability mitigates the amount of greenhouse gas emissions that enter the atmosphere, thereby improving the quality of life (Sassi, 2016). BIM can improve spatial design, especially with regard to airflow evaluation and a building's overall ecosystem (Bonenberg and Wei, 2015). It also can be used to enhance energy simulation and evaluate possible adverse environmental impacts in the context of green assessment (Al-Ghamdi and Bilec, 2015).

The sustainability development in a built environment should integrate social, economic, and environmental aspects simultaneously to work effectively. The integrated approach of these aspects enables sustainability issues to be treated as a complex system rather than concentrate on the "cause and effect" individually (Azapagic and Perdan, 2014). However, the current development of BIM for sustainability is still heavily concentrated on a particular aspect. For instance, an integrated BIM-based electronic procurement system was proposed to provide a new process of collaboration for project stakeholders as per the social sustainability (Grilo and Goncalves, 2011). In terms of economic sustainability, a BIM-based cost-estimating system was created to automate the bill of quantities production (Plebankiewicz et. al., 2015).Wong and Zhou (2015) provided a detailed review of green BIM to magnify the environmental sustainability throughout the building life cycle. A preliminary framework of BIM for future sustainable development was also briefly explained by Chong 
and Wang (2016). There is not yet a comprehensive review of BIM policies or guidelines and BIM uses for sustainability as a whole.

Therefore, this paper provides a mixed review to determine BIM's current state-of-theart development for sustainability. A systematic approach was adopted in reviewing BIM (1) standards and guidelines; and (2) journal and conference papers. Apart from a review from the project life-cycle perspective, this paper has examined two common sustainability aspects in construction projects: (a) the use of products and materials; and (b) energy consumption. The findings provide useful insights as to how BIM can be effectively adapted to the social, economic, and environmental aspects of sustainability.

\subsection{Review approach}

A systematic review method was adopted in this paper, which was structured under a fivestage review approach (Pawson et al., 2015). Figure 1 displays the five-stage analysis framework for reviewing the recent BIM standards and guidelines, journal articles, and conference papers.

Figure 1 Five-Stage Analysis Framework

Step 1: Clarify Scope

Aim: To provide a comprehensive review to determine the current state-of-the-art of BIM development for sustainability.

\begin{tabular}{|l|l|l|l|} 
Key theories to explore:- & $\begin{array}{l}\text { BIM } \\
\text { Academic } \\
\text { publications }\end{array}$ & $\begin{array}{l}\text { BIM Standards } \\
\text { and Guidelines }\end{array}$ \\
\hline \hline No. & Categories & $\begin{array}{l}\text { Did they } \\
\text { address the } \\
\text { sustainability } \\
\text { aspects? }\end{array}$ & $\begin{array}{l}\text { Did they address } \\
\text { the sustainability } \\
\text { aspects? }\end{array}$ \\
\hline 1 & Planning & \\
\cline { 1 - 2 } 2 & Design & Construction & \\
\hline 4 & Operation and Maintenance & & \\
\hline 6 & Refurbishment \& Demolition & & \\
\hline 7 & Ese of Products and Materials & & \\
\hline
\end{tabular}




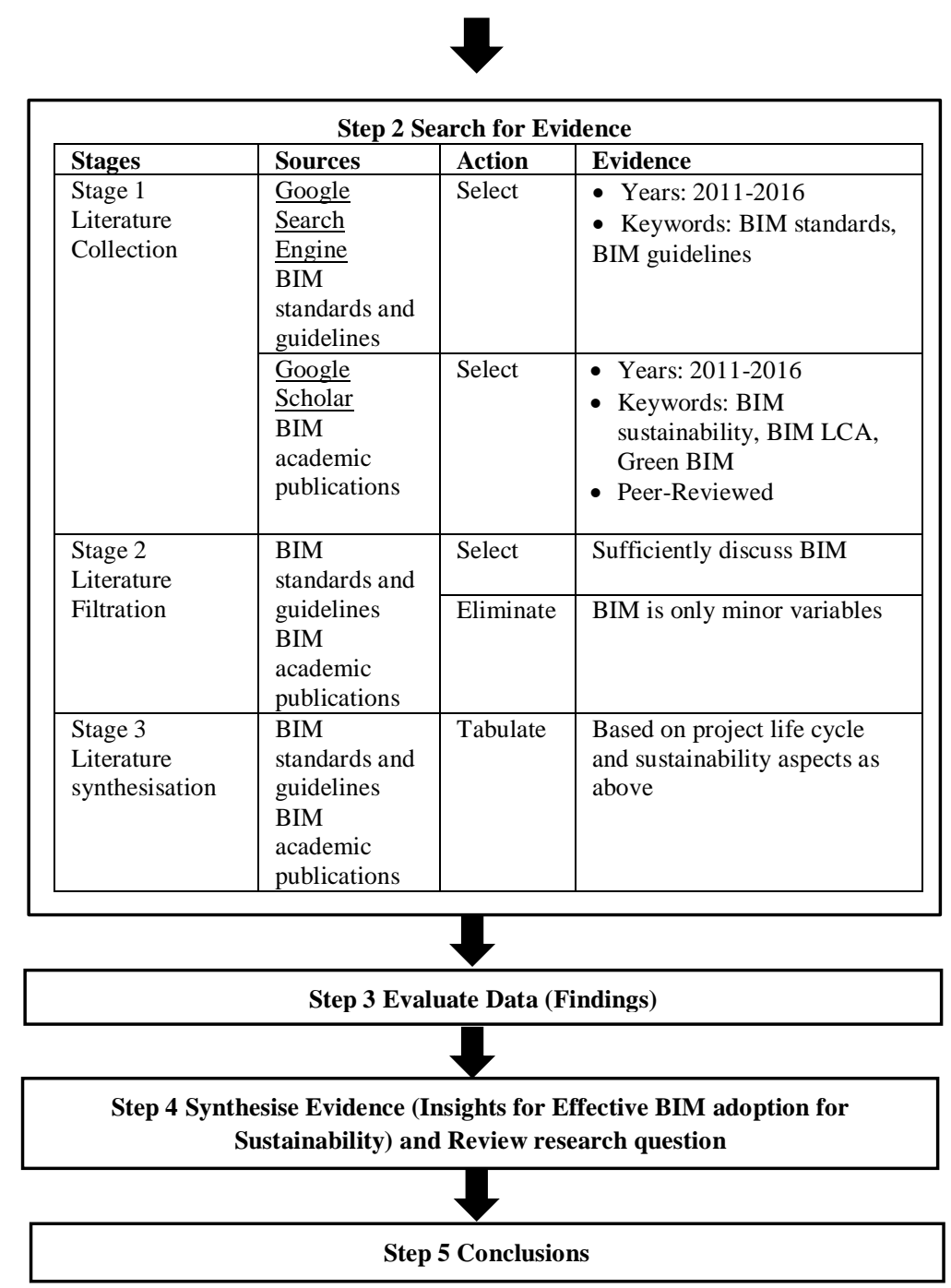

In the earliest stage of the review process, a background study was carried out and research questions were identified that explored the key theories in the study. The ultimate aim of this study is to determine BIM's current state-of-the-art development for sustainability in a built environment.

The second stage involved searching for evidence, which included literature collection, literature filtration, and literature synthesisation. In the literature collection stage, Google Scholar and Google search engine were used to identify the standards or guidelines and 
journals or conference papers that were published by developed countries. These were reliable sources to examine the sustainable development of a built environment. The terms used for sourcing the standards or guidelines were "BIM guidelines" and "BIM standards." The years of the standards and guidelines; and academic publications set in the search machine were from 2011 to 2016 . The search terms were intentionally broad so that any relevant papers were not missed. The terms used were "BIM sustainability," "BIM LCA," and "green BIM." Articles were considered for this review if their titles matched the theme of the keywords. All the journals or conference papers selected were peer reviewed to ensure the quality of the review.

In the literature filtration stage, a detailed examination of the documents was carried out to choose the relevant standards and guidelines; and academic publications for review. If the documents insufficiently described the use of BIM for sustainability, or if the BIM studies were only a minor variable in the files, they were eliminated. Figure 2 shows the years for identified BIM standards or guidelines and academic publications. Most of the standards or guidelines are established in the year 2012, whereas the publications are predominantly published in 2015 .

Figure 2: Comparison of Years for BIM Standards and Guidelines; and Academic Publications

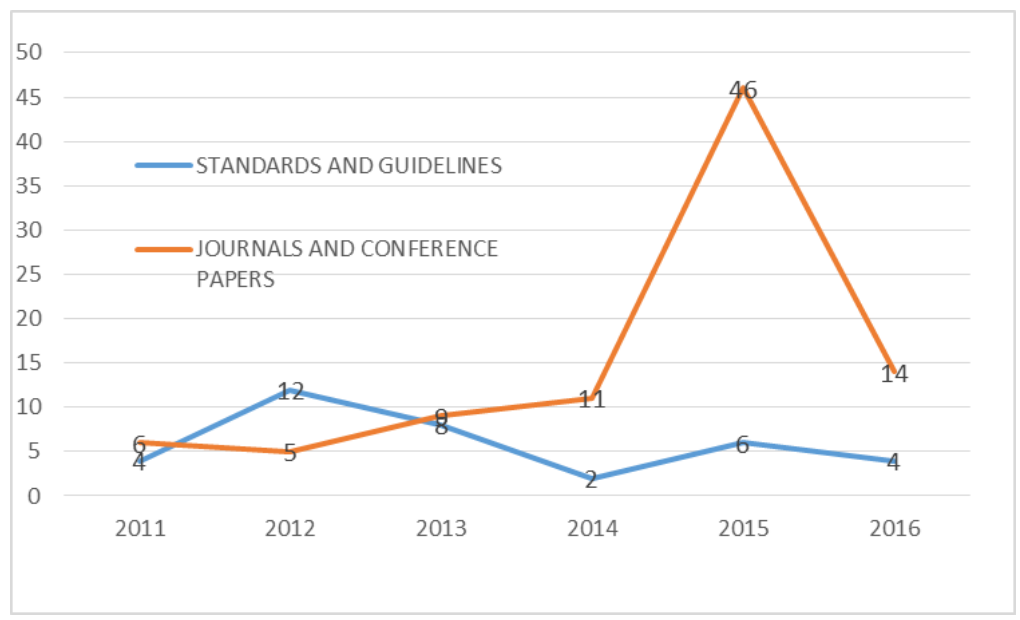


Turning to the literature synthesisation, the selected standards or guidelines and academic publications were tabulated for analysis and further discussion.

According to ISO 14040 (2006), life cycle means "consecutive and interlinked stages of a product system, from raw material acquisition or generation of natural resources to final disposal." The social, economic, and environmental sustainabilities have an effect on each other, and it is hard to separate the discussion of these three contexts. As such, the standards or guidelines and articles were developed from the perspective within the project life cycle only (Chong and Wang, 2016), and they were further classified into the seven categories as follows:

- Planning-This is the most significant phase of a project as it brings the greatest impacts on social, economic, and environmental aspects. It describes a project's overall concept from its inception to the preparation of the design brief. It also includes project delivery planning. BIM could improve the effectiveness and efficiency of project development processes, particularly in mitigating unnecessary waste from re-works and re-planning (Gibbs et al., 2015). With proper planning and development, BIM can help provide a more conducive environment toward sustainability.

- Design-This phase describes the conception design to the selection of a contractor. BIM enables optimum design and coordination among multidisciplinary project participants (Singh et al., 2011).

- Construction-This element deals with the overall construction process starting from site preparation to commissioning. BIM enables early three-dimensional visualisation to predict the cost and schedule of projects (Wang et al., 2014). It reduces construction errors and improves the productivity of projects. 
- Operation and Maintenance-This area indicates the practical completion to postoccupation. Integrated operation management provided by BIM in a virtual environment can facilitate regular maintenance (Chong et al., 2014).

- Refurbishment and Demolition-This stage specifies the work of retrofit or demolition at the end of the life of a project. Yun et al. (2014) demonstrate that the integration of BIM and other digital tools can simulate an existing project to provide the detailed dimensions of every element. It also supports the appropriate method for demolition or refurbishment.

- Use of Products and Materials - The use of materials and products in the project have a robust correlation with the environmental sustainability. A simulated virtual 3D BIM environment enables the testing of building materials (Kim et al., 2015).

- Energy Consumption-This aspect is concerned with relevant techniques and tools used to operate building or infrastructure. Energy simulation software can be used to evaluate the heating, ventilation, air conditioning, and lighting during project life cycle (Ahn et al., 2014).

After the tabulation process, the data were evaluated and discussed in the findings. Based on the analysis results, insights for effective BIM adoption for sustainability were discussed. Thereafter, conclusions were drawn from the analysis and recommendations were proposed to the researchers or practitioners and policy makers.

\subsection{Findings}


Throughout the in-depth review of the standards or guidelines and publications, thirty-six (36) standards and guidelines and ninety-one (91) academic publications were identified and tabulated in Tables 1 and 2.

Table 1: BIM Standards and Guidelines in Different Categories

\begin{tabular}{|c|c|c|c|c|c|c|c|c|}
\hline No & $\begin{array}{l}\text { Standards \& } \\
\text { Guidelines }\end{array}$ & Planning & 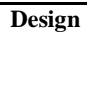 & Construction & $\begin{array}{l}\text { Operation \& } \\
\text { Maintenance }\end{array}$ & $\begin{array}{c}\text { Refurbishment } \\
\text { \& Demolition }\end{array}$ & $\begin{array}{c}\text { Use of } \\
\text { Products \& } \\
\text { Materials }\end{array}$ & $\begin{array}{c}\text { Energy } \\
\text { Consumption }\end{array}$ \\
\hline$\overline{1} 1$ & $\begin{array}{l}\text { ACIF APCC } \\
\text { (2014) }\end{array}$ & $\bar{x}$ & $\bar{x}$ & $\bar{x}$ & $\bar{x}$ & & $\bar{x}$ & $\bar{x}$ \\
\hline 2 & $\mathrm{AEC}(\mathrm{UK}) 2015$ & $\mathrm{x}$ & $\mathrm{x}$ & $\mathrm{x}$ & & & & \\
\hline 3 & AFCEE (2011) & $\mathrm{x}$ & $\mathrm{x}$ & $\mathrm{x}$ & & & & \\
\hline 4 & AGC (2013) & $\mathrm{x}$ & $\mathrm{x}$ & $\mathrm{x}$ & $\mathrm{x}$ & & & \\
\hline 5 & AIA (2013) & $\mathrm{x}$ & $\mathrm{x}$ & $\mathrm{x}$ & $\mathrm{x}$ & & & $\mathrm{x}$ \\
\hline 6 & AMCA (2011) & & $\mathrm{x}$ & $\mathrm{x}$ & & & $\mathrm{x}$ & $\mathrm{x}$ \\
\hline 7 & AOES (2015) & & $\mathrm{x}$ & $\mathrm{x}$ & & & & $\mathrm{x}$ \\
\hline 8 & BCA (2013) & $\mathrm{x}$ & $\mathrm{x}$ & $\mathrm{x}$ & $\mathrm{x}$ & & & $\mathrm{x}$ \\
\hline 9 & $\begin{array}{l}\text { Building SMART } \\
\text { Finland (2012) }\end{array}$ & $\mathrm{x}$ & $\mathrm{x}$ & $\mathrm{x}$ & $\mathrm{x}$ & & $\mathrm{x}$ & $\mathrm{x}$ \\
\hline 10 & CIC (2013) & $\mathrm{x}$ & $\mathrm{x}$ & $\mathrm{x}$ & $\mathrm{x}$ & & & \\
\hline 11 & $\operatorname{COD}(2011)$ & $\mathrm{x}$ & $\mathrm{x}$ & $\mathrm{x}$ & $\mathrm{x}$ & & $\mathrm{x}$ & $\mathrm{x}$ \\
\hline 12 & $\operatorname{COSA}(2011)$ & $\mathrm{x}$ & $\mathrm{x}$ & $\mathrm{x}$ & $\mathrm{x}$ & $\mathrm{x}$ & $\mathrm{x}$ & $\mathrm{x}$ \\
\hline 13 & CPEC (2012) & & $\mathrm{x}$ & $\mathrm{x}$ & $\mathrm{x}$ & $\mathrm{x}$ & & \\
\hline 14 & CPO (2012) & & $\mathrm{x}$ & $\mathrm{x}$ & & & & \\
\hline 15 & DOA/DSF (2012) & $\mathrm{x}$ & $\mathrm{x}$ & $\mathrm{x}$ & $\mathrm{x}$ & & & $\mathrm{x}$ \\
\hline 16 & FMS (2012) & $\mathrm{x}$ & $\mathrm{x}$ & $\mathrm{x}$ & $\mathrm{x}$ & $\mathrm{x}$ & & $\mathrm{x}$ \\
\hline 17 & GSA (2015) & $\mathrm{x}$ & $\mathrm{x}$ & $\mathrm{x}$ & $\mathrm{x}$ & $\mathrm{x}$ & $\mathrm{x}$ & $\mathrm{x}$ \\
\hline 18 & GSFIC (2013) & $\mathrm{x}$ & $\mathrm{x}$ & $\mathrm{x}$ & $\mathrm{x}$ & $\mathrm{x}$ & & $\mathrm{x}$ \\
\hline 19 & GTFM (2016) & $\mathrm{x}$ & $\mathrm{x}$ & $\mathrm{x}$ & $\mathrm{x}$ & $\mathrm{x}$ & $\mathrm{x}$ & $\mathrm{x}$ \\
\hline 20 & HKCIC (2015) & $\mathrm{x}$ & $\mathrm{x}$ & $\mathrm{x}$ & $\mathrm{x}$ & $\mathrm{x}$ & $\mathrm{x}$ & $\mathrm{x}$ \\
\hline 21 & IU (2015) & & $\mathrm{x}$ & $\mathrm{x}$ & $\mathrm{x}$ & & $\mathrm{x}$ & $\mathrm{x}$ \\
\hline 22 & LACCD (2016) & $\mathrm{x}$ & $\mathrm{x}$ & $\mathrm{x}$ & $\mathrm{x}$ & & $\mathrm{x}$ & $\mathrm{x}$ \\
\hline 23 & MIKR (2012) & & $\mathrm{x}$ & $\mathrm{x}$ & & & & \\
\hline 24 & NATSPEC (2016) & $\mathrm{x}$ & $\mathrm{x}$ & $\mathrm{x}$ & $\mathrm{x}$ & & $\mathrm{x}$ & $\mathrm{x}$ \\
\hline 25 & NHBA (2012) & & $\mathrm{x}$ & $\mathrm{x}$ & $\mathrm{x}$ & & $\mathrm{x}$ & $\mathrm{x}$ \\
\hline 26 & NIBS (2015) & $\mathrm{x}$ & $\mathrm{x}$ & $\mathrm{x}$ & $\mathrm{x}$ & $\mathrm{x}$ & $\mathrm{x}$ & $\mathrm{x}$ \\
\hline 27 & NYCDDC(2012) & $\mathrm{x}$ & $\mathrm{x}$ & $\mathrm{x}$ & $\mathrm{x}$ & & $\mathrm{x}$ & $\mathrm{x}$ \\
\hline 28 & NYCSCA (2014) & $\mathrm{x}$ & $\mathrm{x}$ & $\mathrm{x}$ & & & & \\
\hline 29 & OFCC (2012) & $\mathrm{x}$ & $\mathrm{x}$ & $\mathrm{x}$ & $\mathrm{x}$ & $\mathrm{x}$ & $\mathrm{x}$ & $\mathrm{x}$ \\
\hline 30 & PSU (2013) & $\mathrm{x}$ & $\mathrm{x}$ & $\mathrm{x}$ & $\mathrm{x}$ & & & $\mathrm{x}$ \\
\hline 31 & SDCCD (2012) & $\mathrm{x}$ & $\mathrm{x}$ & $\mathrm{x}$ & $\mathrm{x}$ & $\mathrm{x}$ & $\mathrm{x}$ & $\mathrm{x}$ \\
\hline 32 & SEC (2013) & $\mathrm{x}$ & $\mathrm{x}$ & $\mathrm{x}$ & $\mathrm{x}$ & & $\mathrm{x}$ & $\mathrm{x}$ \\
\hline 33 & Statsbygg (2013) & $\mathrm{x}$ & $\mathrm{x}$ & $\mathrm{x}$ & $\mathrm{x}$ & $\mathrm{x}$ & $\mathrm{x}$ & $\mathrm{x}$ \\
\hline 34 & TPA (2016) & $\mathrm{x}$ & $\mathrm{x}$ & $\mathrm{x}$ & $\mathrm{x}$ & & $\mathrm{x}$ & $\mathrm{x}$ \\
\hline 35 & TFC (2012) & $\mathrm{x}$ & $\mathrm{x}$ & $\mathrm{x}$ & $\mathrm{x}$ & & $\mathrm{x}$ & $\mathrm{x}$ \\
\hline \multirow[t]{2}{*}{36} & USACE (2012) & $\mathrm{x}$ & $\mathrm{x}$ & $\mathrm{x}$ & $\mathrm{x}$ & $\mathrm{x}$ & $\mathrm{x}$ & $\mathrm{x}$ \\
\hline & TOTAL & 29 & 36 & 36 & 29 & 12 & 21 & 28 \\
\hline
\end{tabular}


Table 2: Academic Publications in Different Project Categories

\begin{tabular}{|c|c|c|c|c|c|c|c|c|}
\hline No & $\begin{array}{l}\text { Academic } \\
\text { Publications }\end{array}$ & Planning & $\overline{\text { Design }}$ & Construction & $\begin{array}{l}\text { Operation \& } \\
\text { Maintenance }\end{array}$ & $\begin{array}{l}\text { Refurbishment } \\
\text { \& Demolition }\end{array}$ & $\begin{array}{c}\text { Use of } \\
\text { Products } \\
\& \\
\text { Materials }\end{array}$ & $\begin{array}{c}\text { Energy } \\
\text { Consumption }\end{array}$ \\
\hline 1 & $\begin{array}{l}\text { Abanda \& Byers } \\
(2016)\end{array}$ & & & & & & & $\mathrm{x}$ \\
\hline 2 & Adeyemi et al (2014) & & & & $\mathrm{x}$ & & & \\
\hline 3 & Ajayi et al (2015) & & $\mathrm{x}$ & & & & $\mathrm{x}$ & \\
\hline 4 & Akinadea et al (2015) & & & & & $\mathrm{x}$ & & \\
\hline 5 & Alwan et al (2015) & & $\mathrm{x}$ & & & & & $\mathrm{x}$ \\
\hline 6 & $\begin{array}{l}\text { Anton and Diaz } \\
\text { (2014) }\end{array}$ & & $\mathrm{x}$ & & & & & \\
\hline 7 & Arayici et al (2014) & & $\mathrm{x}$ & & & & & \\
\hline 8 & Arthur (2015) & & & & $\mathrm{x}$ & & $\mathrm{x}$ & $\mathrm{x}$ \\
\hline 9 & Asl et al (2015) & & $\mathrm{x}$ & & & & $\mathrm{x}$ & $\mathrm{x}$ \\
\hline 10 & Azha et al (2011) & & $\mathrm{x}$ & & & & $\mathrm{x}$ & $\mathrm{x}$ \\
\hline 11 & $\begin{array}{l}\text { Barazzetti et al } \\
(2015)\end{array}$ & & $\mathrm{x}$ & & $\mathrm{x}$ & $\mathrm{x}$ & & \\
\hline 12 & Basbagill et al (2013) & & & & & & & \\
\hline 13 & $\begin{array}{l}\text { Bonenberg \& Wei } \\
\text { (2015) }\end{array}$ & $\mathrm{x}$ & $\mathrm{x}$ & $\mathrm{x}$ & & & $\mathrm{x}$ & $\mathrm{x}$ \\
\hline 14 & Bosche et al (2015) & & & $\mathrm{x}$ & & $\mathrm{x}$ & & \\
\hline 15 & Ceranic et al (2015) & & $\mathrm{x}$ & $\mathrm{x}$ & & & $\mathrm{x}$ & $\mathrm{x}$ \\
\hline 16 & Chen \& Pan (2015) & & $\mathrm{x}$ & & & & $\mathrm{x}$ & $\mathrm{x}$ \\
\hline 17 & Cheng \& Das (2014) & & $\mathrm{x}$ & & & & & $\mathrm{x}$ \\
\hline 18 & Cheng \& Ma (2013) & & & & & $\mathrm{x}$ & $\mathrm{x}$ & \\
\hline 19 & Chiang et al (2015) & & & & $\mathrm{x}$ & & & $\mathrm{x}$ \\
\hline 20 & Cho et al (2012) & & $\mathrm{x}$ & $\mathrm{x}$ & & & & $\mathrm{x}$ \\
\hline 21 & Ciribini et al (2015) & $\mathrm{x}$ & & & & & & \\
\hline 22 & $\begin{array}{l}\text { Costa \& Madrazo } \\
\text { (2015) }\end{array}$ & & & $\mathrm{x}$ & & & & \\
\hline 23 & Costa \& Grilo (2016) & $\mathrm{x}$ & & & & & & \\
\hline 24 & $\begin{array}{l}\text { Francom \& Asmar } \\
\text { (2015) }\end{array}$ & & & $\mathrm{x}$ & & & & \\
\hline 25 & Geyer (2012) & & $\mathrm{x}$ & & & & & \\
\hline 26 & $\begin{array}{l}\text { Grilo \& Goncalves } \\
\text { (2011) }\end{array}$ & & & & & & & \\
\hline 27 & $\begin{array}{l}\text { Hajibaibai et al } \\
\text { (2011) }\end{array}$ & & $\mathrm{x}$ & & & & & \\
\hline 28 & $\begin{array}{l}\text { Ho \& Rajabifard } \\
\text { (2016) }\end{array}$ & $\mathrm{x}$ & & & & & & \\
\hline 29 & $\begin{array}{l}\text { Holmstrom et al } \\
\text { (2015) }\end{array}$ & & $\mathrm{x}$ & $\mathrm{x}$ & $\mathrm{x}$ & & & \\
\hline 30 & Hou et al (2014) & & $\mathrm{x}$ & $\mathrm{x}$ & & & & \\
\hline 31 & $\begin{array}{l}\text { Ilhan \& Yaman } \\
(2016)\end{array}$ & & $\mathrm{x}$ & & & & $\mathrm{x}$ & $\mathrm{x}$ \\
\hline 32 & Inyim et al (2015) & & $\mathrm{x}$ & & & & & \\
\hline 33 & Irizarry et al (2013) & & & $\mathrm{x}$ & & & & \\
\hline 34 & Jalaei \& Jrade (2014) & & $\mathrm{x}$ & & & & $\mathrm{x}$ & $\mathrm{x}$ \\
\hline 35 & Jalaei \& Jrade (2015) & & $\mathrm{x}$ & & & & & $\mathrm{x}$ \\
\hline 36 & Jones (2014) & $\mathrm{x}$ & & & & & & \\
\hline 37 & Jrade \& Jalaei (2013) & & $\mathrm{x}$ & & & & & \\
\hline 38 & Jung et al (2015) & & & & & $\mathrm{x}$ & & \\
\hline 39 & $\begin{array}{l}\text { Kapogiannis et al } \\
(2015)\end{array}$ & & $\mathrm{x}$ & $\mathrm{x}$ & $\mathrm{x}$ & & $\mathrm{x}$ & $\mathrm{x}$ \\
\hline 40 & $\begin{array}{l}\text { Karan \& Irizarry } \\
(2015)\end{array}$ & & & $\mathrm{x}$ & & & & \\
\hline 41 & $\begin{array}{l}\text { Khaddaj \& Srour } \\
(2016)\end{array}$ & & & & & $\mathrm{x}$ & & \\
\hline 42 & $\begin{array}{l}\text { Kim \& Anderson } \\
(2013)\end{array}$ & & $\mathrm{x}$ & & & & & $\mathrm{x}$ \\
\hline 43 & Kim et al (2015a) & & $\mathrm{x}$ & & & & & \\
\hline 44 & Kim et al. (2015b) & & $\mathrm{x}$ & & & & & $\mathrm{x}$ \\
\hline 45 & Kim et al (2015c) & $\mathrm{x}$ & & & & & & \\
\hline 46 & Kim et al (2016) & & $\mathrm{x}$ & & & & $\mathrm{x}$ & $\mathrm{x}$ \\
\hline 47 & $\begin{array}{l}\text { Korkmaz et al } \\
(2013)\end{array}$ & $\mathrm{x}$ & & & & & & \\
\hline
\end{tabular}




\begin{tabular}{|c|c|c|c|c|c|c|c|c|}
\hline 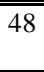 & $\begin{array}{l}\text { Kovacic et al } \\
(2015)\end{array}$ & & $\mathrm{x}$ & & & & $\bar{x}$ & $\overline{\mathrm{x}}$ \\
\hline 49 & $\begin{array}{l}\text { Kumar \& Cheng } \\
(2015)\end{array}$ & & & $\mathrm{x}$ & & & & \\
\hline 50 & $\begin{array}{l}\text { Kylili \& Vaicinas } \\
\text { (2015) }\end{array}$ & & $\mathrm{x}$ & & $\mathrm{x}$ & & $\mathrm{x}$ & \\
\hline 51 & Lee et al (2015) & & $\mathrm{x}$ & & & & $\mathrm{x}$ & \\
\hline 52 & Lin et al (2015) & & & $\mathrm{x}$ & & & & $\mathrm{x}$ \\
\hline 53 & Liu et al (2015) & & $\mathrm{x}$ & & & & & \\
\hline 54 & Maia et al (2015) & & $\mathrm{x}$ & & & & & \\
\hline 55 & $\begin{array}{l}\text { Matthew et al } \\
\text { (2015) }\end{array}$ & & & $\mathrm{x}$ & & & & \\
\hline 56 & $\begin{array}{l}\text { McGuire et al } \\
\text { (2016) }\end{array}$ & & & & $\mathrm{x}$ & & & \\
\hline 57 & $\begin{array}{l}\text { Means \& } \\
\text { Guggemos (2015) }\end{array}$ & & & & & & & \\
\hline 58 & $\begin{array}{l}\text { Motawa \& Carter } \\
\text { (2013) }\end{array}$ & & & & $\mathrm{x}$ & & & $\mathrm{x}$ \\
\hline 59 & $\begin{array}{l}\text { Mousa et al. } \\
(2016)\end{array}$ & & & & $\mathrm{x}$ & & $\mathrm{x}$ & \\
\hline 60 & Nawari (2012) & & & $\mathrm{x}$ & & & & \\
\hline 61 & Ness et al (2015) & & $\mathrm{x}$ & & & $\mathrm{x}$ & $\mathrm{x}$ & \\
\hline 62 & $\begin{array}{l}\text { Nguyen et al } \\
\text { (2015) }\end{array}$ & & $\mathrm{x}$ & & & & $\mathrm{x}$ & $\mathrm{x}$ \\
\hline 63 & $\begin{array}{l}\text { Nicknam \& } \\
\text { Karshenas (2015) }\end{array}$ & & $\mathrm{x}$ & & & & & $\mathrm{x}$ \\
\hline 64 & Niu et al (2015) & & $\mathrm{x}$ & & & & & $\mathrm{x}$ \\
\hline 65 & $\begin{array}{l}\text { Oti \& Tizani } \\
\text { (2015) }\end{array}$ & & $\mathrm{x}$ & & & & & \\
\hline 66 & Oti et al. (2016) & & $\mathrm{x}$ & & & & & \\
\hline 67 & Peng (2016) & & $\mathrm{x}$ & & & & & $\mathrm{x}$ \\
\hline 68 & $\begin{array}{l}\text { Porwal \& Hewage } \\
(2012)\end{array}$ & & $\mathrm{x}$ & & & & & \\
\hline 69 & $\begin{array}{l}\text { Porwal \& Hewage } \\
\text { (2013) }\end{array}$ & $\mathrm{x}$ & & & & & & \\
\hline 70 & Ren et al (2012) & & & $\mathrm{x}$ & & & & \\
\hline 71 & $\begin{array}{l}\text { Ryu \& Pack } \\
(2016)\end{array}$ & & $\mathrm{x}$ & & & & & $\mathrm{x}$ \\
\hline 72 & Said (2015) & & & $\mathrm{x}$ & & & & \\
\hline 73 & Sebastian (2011) & $\mathrm{x}$ & & & & & & \\
\hline 74 & Shafiq et al (2015) & & $\mathrm{x}$ & & & & $\mathrm{x}$ & \\
\hline 75 & $\begin{array}{l}\text { Shen \& Marks } \\
(2015)\end{array}$ & & & $\mathrm{x}$ & & & & \\
\hline 76 & Shi et al (2016) & & & & $\mathrm{x}$ & & & \\
\hline 77 & Shin \& Cho (2015) & & $\mathrm{x}$ & & & & $\mathrm{x}$ & \\
\hline 78 & Smith (2014) & & $\mathrm{x}$ & & & & & \\
\hline 79 & $\begin{array}{l}\text { Swarup et al } \\
\text { (2011) }\end{array}$ & & & & & & & \\
\hline 80 & $\begin{array}{l}\text { Tahmasebi et al } \\
\text { (2011) }\end{array}$ & & $\mathrm{x}$ & & & & & $\mathrm{x}$ \\
\hline 81 & $\begin{array}{l}\text { Wang \& Cho } \\
(2015)\end{array}$ & & & & & & & $\mathrm{x}$ \\
\hline 82 & $\begin{array}{l}\text { Wang \& Shen } \\
(2016)\end{array}$ & & $\mathrm{x}$ & & & & & $\mathrm{x}$ \\
\hline 83 & Wang et al (2015) & & & & $\mathrm{x}$ & $\mathrm{x}$ & & \\
\hline 84 & $\begin{array}{l}\text { Wezet \& Thabet } \\
\text { (2015) }\end{array}$ & & & & $\mathrm{x}$ & & & \\
\hline 85 & $\begin{array}{l}\text { Wong \& Kuan } \\
\text { (2014) }\end{array}$ & & $\mathrm{x}$ & & & & $\mathrm{x}$ & $\mathrm{x}$ \\
\hline 86 & Wu \& Issa (2015) & $\mathrm{x}$ & $\mathrm{x}$ & $\mathrm{x}$ & $\mathrm{x}$ & & $\mathrm{x}$ & $\mathrm{x}$ \\
\hline 87 & $\mathrm{Xu}$ et al (2014) & & $\mathrm{x}$ & $\mathrm{x}$ & $\mathrm{x}$ & & & \\
\hline 88 & $\begin{array}{l}\text { Yeheyis et al } \\
(2013)\end{array}$ & & & & & $\mathrm{x}$ & $\mathrm{x}$ & \\
\hline 89 & $\begin{array}{l}\text { Yenumula et al } \\
(2015)\end{array}$ & & & & $\mathrm{x}$ & & & \\
\hline 90 & $\begin{array}{l}\text { Yung \& Wang } \\
(2014)\end{array}$ & & $\mathrm{x}$ & $\mathrm{x}$ & & & $\mathrm{x}$ & $\mathrm{x}$ \\
\hline 91 & Zhang et al. (2016) & & & $\mathrm{x}$ & & & & \\
\hline
\end{tabular}




\begin{tabular}{|l|l|l|l|l|l|l|l|l||}
\hline & TOTAL & 10 & 48 & 22 & 16 & 9 & 24 & 31 \\
\hline
\end{tabular}

The results show that most of the BIM standards and guidelines concentrated on planning, design, construction, and operation and maintenance. The research trend of BIM for sustainability was apparent in the design, construction, use of products and materials, and energy efficiency. As the design phase serves as an important foundation for BIM implementation in projects, it was the significant focus for industry and academia.

Refurbishment and demolition also bring greater influence toward sustainability. But the standards, guidelines, and even academic publications in these two areas are rather limited. The number of BIM standards and guidelines and academic publications that covered aspects of refurbishment and demolition were only twelve (12) and eight (8), respectively.

In addition, the academic publications that addressed the sustainability aspects of planning and the operation and maintenance phase were only nine (9) and fourteen (14), respectively. Each stage of the project's life cycle has been elaborated as follows:

\subsection{Planning}

Social sustainability provides a safe, conducive, and healthy environment for all involved in the process irrespective of owners, designers, contractors, subcontractors, or end users (Zuoand Zhao, 2014). According to MacLeamy's curve (MacLeamy, 2004), BIM implementation in the early stage of the project, such as during procurement and the early 
design stage, will minimise the variation costs and make projects more accommodating (Holzer, 2009). Most of the standards provide a clear guide that if BIM is to be implemented, the procurement strategy has to be outlined in advance. NATSPEC (2016) provided a few options of procurement systems for team members and, based on the selected procurement strategy, it required team members to delineate the details of their work for handling the model from the initial stage of the project. To avoid conflicts in the scope of the work, the standard even suggested that the BIM Management Plan should address how the model is to be effectively transferred among responsible parties with minimal effort.

ACIF and APCC (2014) encouraged project owners to engage the design consultant and contractor at the earliest stage of the project to foster project integration. It is noted that BIM standards or guidelines are not intended as a replacement for the standard project delivery and contract but as a supplement to facilitate smooth project deliverables (GSFIC, 2013).

The amount of innovative research into BIM adoption in project planning and procurement systems for sustainability is rather limited. For project planning, a cyclical framework that outlined a strategy for change to the institutional environment for supporting the move toward BIM-enabled land administration in the Singapore urban area was developed (Ho and Rajabifard, 2016). An automated system combining BIM, Development Strategy Formulation and Evaluation Methodology (DSFEM), and Development Strategy Simulator (DSS) was created as a decision-support tool for stakeholders to evaluate a variety of alternative plans based on the visualization of actual development and construction provided by the integrated system (Kim et al., 2015c). An Auto-CAD Civil 3D BIM model and other environmental analysis software were used to resolve planning issues for site 
location, climate condition, ecological value, site information, and transport infrastructure for the Tent Hotel in Hengshan NaShan village (Bonenberg and Wei, 2015). All these studies ensure that optimal decisions are made for the appropriateness of land use and thereby improve social, economic, and environmental aspects for sustainability.

Turning to an aspect of procurement strategy that creates a pleasant and sustainable working environment, the study showed that the use of a procurement system would influence the ability of the client to achieve sustainability goals (Korkmaz et al., 2012). Jones (2014) established a conceptual intelligent collaborative framework that included Integrative Project Delivery (IPD), Virtual Design and Construction (VDC), and 3D to 5D BIM, based on the challenges identified by different construction practitioners. This framework allows project participants to interact and solve the time, cost, quality, constructability, safety, and other associated issues before the commencement of projects. Wu and Issa (2015) created a procurement framework that facilitated green BIM practices based on the overall business process and executed planning.

In terms of economy sustainability, the implementation of BIM saves time and leads to an increase in work efficiency. It enhances the e-procurement system, which allows consultants to carry out model checking and to control the compliance of a client's requirement and to evaluate the tenderers' offers (Ciribini et al., 2015). Costa and Grilo (2015) developed a BIM-based e-procurement prototype to improve product development, manufacturing, and logistics. The prototype differs from conventional e-procurement, which is predominantly concentrated on the purchasing requirement and the use of real-time communication to exchange information. Sebastian (2011), on the other hand, studied the impacts of BIM adoption on the conventional roles of project participants using the 
traditional procurement route. This study is important for contributing social sustainability as it has the potential to identify any adverse relationship that occurs during the process that will affect the harmonious relationship of project team members. Porwal and Hewage (2013) proposed a BIM-based partnering framework in the public procurement system. The BIM tools were used from the inception to construction stage, which included selected subcontractors to partner with the government before the design brief was received from the client.

\subsection{Design}

The design is the core element encompassed in most of the BIM standards or guidelines. Social, economic, and environmental sustainability depends on the matter of design. The study showed that a BIM-based sustainability simulation during the early or pre-design stage is crucial to developing a sustainable building design (Lim, 2015). Bonenberg and Wei (2015) asserted that using BIM enabled the creation of a sustainable design that can analyse the impact of green building, particularly in building performance, adoption of materials, and energy efficiency. To ensure compliance with client requirements, DOA/DSF (2012) outlined all BIM deliverables and must demonstrate that the design is on track to satisfy the owner's requirements for sustainability, codes, operations, technical elements, constructability, cost, and schedule. HKCIC (2015) required all project participants, which include downstream subcontractors, to use authoring tools for producing fabrication and shop drawing and scheduling of finishes in building and infrastructure works.

To work toward sustainability, BIM standards or guidelines demystified the good practice of model coordination. BCA (2013) stated that users of the model should bear the 
responsibility of checking, verifying, and confirming the accuracy of the model. AIA (2013) outlined the detailed responsibilities of parties that managed the model, which included collecting incoming models, aggregating model files and making models for viewing, performing clash detection, maintaining model archives and backups, managing access rights, and following established protocol. In regard to the additional sharing of liabilities with designers, the BIM standards make a fair compensation to the designers (BCA, 2013). Also, to facilitate the coordination responsibilities in the project, the information manager is required by the client to manage the data (CIC, 2013). AEC (UK) (2015) requested that all staff dealing with the model must possess technology skills.

It is apparent that the majority of BIM was mainly adopted to utilise its visualisation capacity. Arayici et al. (2011) demonstrated the use of technology to improve the quality, speed, and cost of an architectural firm. With the adoption of BIM, the model can automatically adapt to changes through the parametric relationship between objects. The use of BIM encourages information sharing among project participants, and through visualization, design errors can be discovered. This has led to better financial control of the project and offers more flexibility to satisfy clients' needs. Hajibabai et al. (2011) used computer-aided design (CAD) to synchronize a project's schedule in a Microsoft Excel file, and geographic information systems (GIS) to link with scheduling and spatial data to assist stakeholders in visualising and analysing greenhouse gas emissions generated from construction works. Niu et al. (2015) developed an energy data visualization system via webbased BIM-GIS to visualise an urban energy landscape's design. To improve the sustainability of infrastructure projects, Kim et al. (2015a) used GIS and BIM to visualise the existing walkability of the Safe Routes to School Programme (SRTS). This visualisation is important in assessing the appropriateness of existing routes. It allowed more children to 
walk to school and promoted health and safety, and thereby minimised energy consumption and $\mathrm{CO}_{2}$ emission.

Collaborative efforts were observed to improve the productivity of team members. An integrated system of Semantic BIM and Semantic Web Services was created to allow the collection of information from several sources of energy for analysis over the Internet. This more efficient method will allow designers to extract data from different energy analysis applications (Nicknam and Karshenas, 2015). Cheng and Das (2014) developed a modular web service framework to combine all the necessary green assessment and building design information, automate the process of building evaluation, and facilitate BIM updates on an easily available collaboration platform. Xu et al. (2015) built an integrated BIM-based information management system for a project life cycle despite each consultant creating their own model. Kim et al. (2015b) developed a Modelica library for a BIM-based building energy simulation through the Object-Oriented Physical Modeling (OOPM) approach to improve complex data exchange between building design and energy simulation software. Xu et al. (2014) invented BIM-based life-cycle information management so that BIM data could be shared and simultaneously utilized by project participants while also ensuring data integrity.

Anton and Diaz (2015) contended that the Life Cycle Assessment (LCA) performance should be calculated via direct access to BIM information. However, most of the life-cycle assessment required integration of BIM with other software. For instance, Ajayi et al. (2015) connected Revit Architecture with an energy-simulation tool, such as Green Building Studio (GBS) and the life-cycle impact-assessment tool ATHENA Impact Estimator, to investigate the negative impacts arising from the use of numerous building 
materials and energy performance. Tahmasebi et al. (2011) used ArchiCad 14 BIM software and Grafosoft EcoDesigner to calculate the carbon footprint and energy consumption of multiglazed windows based on the changes made in the building. Chen and Pan (2015) also established a BIM-integrated prototype that combined Revit Architecture, eQUEST simulation software, a multicriteria decision-making (MCDM) model based on Fuzzy PROMETHEE, and Low Impact Design Explorer (LIDX) to select measures of a low-carbon building (LCB). A sensitivity analysis had been incorporated in BIM to identify the embodied environmental impacts based on the dimensions and materials of building elements (Basbagill et al., 2013). Shafiq et al. (2015) incorporated Model M1 (G25XS280) to a BIM-based design building to quantify, evaluate, and select various embodied colour footprints of structural materials.

\subsection{Construction}

In this phase, LACCD (2016) emphasised that it did not require 4D animation. It encouraged the contractor to create a schedule-based visualisation model that linked to the sequence of construction. On the other hand, TPA (2016) stipulated that 4D or 5D simulations should be used to their full extent, such as for project forecasting, interface management, and logistic planning.

GTFM (2016) mandated that designers and contractors work concurrently, and it even stipulated that the designers were required to maintain and update the design models consistently with any changes during construction. AEOC (2015) expected the designers to continue to update the design-intent model with any changes during construction. 
In working toward sustainability, BIM can be used to facilitate the project information. For example, Lin (2014) invented a Construction BIM-based Knowledge Management (CBIMKM) system that combined BIM and web technology, which enabled explicit and tacit knowledge of project participants to be shared and reused during the construction phase. BIM was also used to ease the selection of material suppliers during the construction process. Nawari (2012) proposed that BIM use the Information Delivery Manual (IDM) during the off-site construction process (Nawari, 2012). Information extracted from BIM can be used to fabricate modular units (Zhang et al., 2016), which allows less costly materials to be wasted, reduces site disturbance and air pollution, and increases the flexibility of design change and re-use.

To assess the pricing submitted by material suppliers, Ren et al. (2012) established a framework for integrating BIM data with unit price cost data to produce accurate estimating reports for evaluation of suppliers' performance. BIM was also used to facilitate the manufacturing process of construction output. Costa and Madrazo (2015) used existing BIM technologies and the Semantic Web to link the BIM information with structural precast concrete component profiles to assist consultants and contractors with assembling and dimensioning structural components during construction.

To support construction planning, Kumar and Cheng (2015) created an automated framework for generating dynamic site layout models. An algorithm is used with genetic algorithms to optimise the travel distance for equipment and construction personnel. An integrated BIM and geographic information system (GIS) were designed to monitor the supply chain and provide warning signals about potential problems (Irizarry et al., 2013). 
BIM also can help generate prediction models for the prefabrication feasibility of electrical contractors (Said, 2015).

Apart from planning, BIM was used for monitoring construction progress. Bosche et al. (2015) created a "Scan-vs-BIM" to track the discrepancies between as-planned and asbuilt mechanical, electrical, and plumbing elements. A cloud-based BIM was created to deliver on-site real-time information of the reinforced concrete structure (Matthew et al., 2015). During the fabrication stage, BIM can integrate with Augmented Realty (AR) to visualise and facilitate pipe assembly for increasing accuracy of work (Hou et al., 2014). BIM has also proven to reduce changes ordered by clients owing to better understanding through visualisation, which leads to more productive involvement of owners during the construction process. BIM can also reduce latent defect costs (Francomand Asmar, 2015). To ensure safety, a near-miss database generated from BIM software can provide visualisation to construction personnel that alerts them to hazardous areas and reports any near-misses (Shen and Marks, 2015).

\subsection{Operation and Maintenance}

The operation and maintenance phase plays a significant role in maintaining built environment sustainability. Whereas most of the guidelines indicated that the responsibility of passing the models relied on designers and contractors, SDCCD (2012) indicated that the facility management department would ensure the safe and secure operations and maintenance environment of the assets in a cost-effective manner for preserving asset value in the long term. AIA (2013) required that the model include operation and maintenance 
manuals. COD (2011) specified that the model and facility data fulfil the requirements of Construction Operations Building Information Exchange (COBIE).

BIM can be used to eliminate waste and inefficient facilities in existing buildings. Adeyemi et al. (2014) proposed a strategy framework that incorporated lean thinking, zero emission, and green building into the BIM to reduce the cost of maintenance rather than demolishing and rebuilding properties. The built environment can also benefit by extending the function of BIM to facility management and real-time building operations (Arthur, 2015). Chiang et al. (2015) designed a platform called Real-Time Replay System (RTRS), which utilised the information generated by Revit (a BIM tool), a WiFi power socket sensor, and Unity 3D to replay electricity usage events. This interactive smart system presented the potential to conserve energy and allow the consumer to alter the scene or jump to the period indicated as a wasteful operation. Moreover, the consumer can set up an event that triggers the parameter conditions in the sensor database. This innovative system could help end users manage the consumption of electricity, thereby minimising time and efforts for identifying raw information.

To maintain existing buildings, BIM is usually manually created through point cloud data that is time, cost, and labour intensive. Wang et al. (2015) invented an automation system to extract building geometries from unorganized point clouds. It downsized the collected data and detected the boundary to categorise it into building components. Most of the life-cycle assessment of the BIM study was adopted in the design stage. But a conceptual systematic BIM-based model to monitor building behaviour has been established by Motawa and Carter (2013) during the post-occupancy stage to improve the post-occupancy evaluation process and meet the industry standard requirements for sustainable buildings. 


\subsection{Refurbishment and Demolition}

The study showed that the construction sector recorded $40 \%$ of energy consumption in Europe, and more than $40 \%$ of Europe's existing buildings were more than 50 years old (European Directive, 2010). One of the most effective ways to reduce carbon emissions is through the renovation of existing buildings to reduce energy consumption. By doing so, air pollution can be mitigated, and the indoor climate improved, which leads to healthier living (Kylili et al., 2016). But there are not many BIM standards and guidelines established for refurbishment and demolition as compared to other categories.

COSA (2011) required Industry Foundation Classes (IFC)-compliant BIM tools to be used in all major construction and renovation projects that exceeded $\$ 3$ million in construction value. CPEC (2012) specified that designers are required to submit complete construction documents for any renovation projects to the owner before beginning the project. HKCIC (2015) stated that BIM was to include spatial tracking software for analysing existing space usage to apply transition planning for refurbishment projects. Existing site conditions should be modelled (SDCCD, 2012) for renovation projects.

Khaddaj and Srour (2016) proposed a research framework to enhance the roles of BIM in energy-driven retrofits. Akainade et al. (2015) designed a BIM-based Deconstructability Assessment Score (BIM-DAS) for determining the extent to which a building could be deconstructed from the design stage. Besides, an integration BIM-based system was created to estimate the amount of waste generated from construction, renovation, and demolition. This system was capable of extracting quantities of materials from the BIM 
model and estimating the amount of waste produced from each project phase. This research is important to improving the sustainability of demolition and renovation projects to facilitate project control (Cheng and Ma, 2013). Yeheyis et al. (2013) proposed a conceptual waste management framework to optimize $3 \mathrm{R}$ (reduce, reuse, and recycle). An automated as-built 3D BIM model was created for designing a building's interior because an industry always experiences critical issues of design complexity, and a substantial amount of clutter from scanned point clouds (Jung et al., 2015). Wang and Cho (2015) have developed an automated energy simulation system to simplify BIM creation from point clouds for existing buildings. This system provides in-depth visualisation and information to decision makers on refurbishment projects.

\subsection{Use of Products and Materials}

USACE (2012) required projects to be evaluated based on LEED or other sustainable criteria, which includes materials, performance, or a process of planning, design, construction, and operation. Statsbygg (2013) required the contractor to update the changes by including material property such as fire rating property to a window. SDCCD (2012) requested that the piping model include material, size, slope, and elevation of the pipe. GTFM (2016) even requested designers to present three alternatives for site placement and building footprint; finishes and materials; and general space program plan and layouts.

Many approaches have been adopted by researchers to evaluate embodied carbon impacts on products and materials. One approach collects, analyses, and views the building's carbon emissions data by combining BIM and carbon estimation models to assist operation teams in discovering issues of carbon emissions (Mousa et al., 2016). BIM was integrated 
with the life-cycle assessment (LCA) tool to identify the sustainability of piping material (Kylili and Vaiciunas, 2015). By adopting the system, the performance of the Vernetztes Polyethylene (VPE) water supply system has been proven to be better than the steel system and the copper system. The VPE system released a lesser amount of carbon dioxide as compared to the other two systems. A BIM-based design with Excel spreadsheet for LCA and life-cycle costing assessment (LCCA) were developed by Shin and Cho (2015) to appraise the alternative materials for external cladding.

Lee et al. (2015) used an LCA method and a BIM-based design to evaluate the adverse effects of the substances produced from concrete production. These included environmental impact categories such as global warming (GWP), acidification (AP), eutrophication (EP), abiotic depletion (ADP), ozone depletion (ODP), and photochemical oxidant creation (POCP). Inyim et al. (2015) integrated a Simulation of Environmental Impact of Construction (SimulEICon) with Autodesk Revit Architecture software and genetic algorithm (GA), NSGA-II to provide optimal solutions for building components selection and to visualise the model in 3D or 4D for better decision making.

\subsection{Energy Consumption}

GSFIC (2013) demanded that architects and engineers use early energy simulation software coupled with BIM to create comparative energy analysis. It specified that the criteria of modelling should be based on information of local climate and actual site conditions. The approach is similar to that of DOA/DSF (2009), which indicated that the outcome of modelling should demonstrate how various architectural variables such as sun controls, natural ventilation, and daylighting can be used to optimise the design. GSA (2015) had a 
special provision for an energy-modelling selection. It detailed the data requirement of energy modelling in every project's life cycle. It is also observed that some standards and guidelines requested the energy modelling to comply with standard sustainability assessment such as LEED.

In the design phase, Asl et al. (2015) developed a BIM-Based Performance Optimization (BPOpt) to probe the effects of different design alternatives on energy performance through an open-source visual programming user interface and cloud-based simulation. Kim et al. (2016) assessed the impact of window size, position, and orientation on building energy load using BIM. Ceranic et al. (2015) presented an integrated approach that uses BIM and sustainable design analysis (SLA) so that energy calculations could be predetermined before referring to the exact specification of building materials, which has significantly minimised the modelling time. In their study, Cho et al. (2012) identified a few effective energy-simulation tools, namely, Energy Plus, IES, and Virtual Environment, to integrate with BIM so that ordinary stakeholders could easily perform energy-performance analysis. A parametric modelling system for sustainability building design has been established to show the generic model of structure design and flow of energy so that it could be integrated into the BIM CAD design process (Geyer, 2012).

During the construction phase, energy analyses can be used to analyse equipment selections made by contractors and to define the energy consumption targets for the future operation of the building. As for operation and maintenance, the effects of the changes that occurred in the operation can be further evaluated and updated to the target user. Moreover, energy analyses can be utilized in cases of malfunctions and in resolving issues and comparing repair options (Building SMART Finland, 2012b). 
Some research efforts of matching the BIM in standard sustainability assessment are apparent. Ilhan and Yaman (2016) developed a green building assessment tool (GBAT) that extracted the required data from BIM to calculate the green rating and provides feedback for further evaluation. Alwan et al. (2015) developed an intelligent process to streamline the LEED assessment method with the building designed with BIM to simplify the environmental assessment process and thereby reduce the environmental impact. The LEED assessment documents could be incorporated in BIM-based sustainability analysis software, which saves substantial time and resources for preparing LEED certification when compared to the conventional approach (Azhar et al., 2011). Jalaei and Jrade (2015) also used a similar concept, but with a different approach, to incorporate the LCA module, LEED module, cost module, and BIM module from different resources such as suppliers, publishers, Internet, and literature to design, simulate, analyse, and evaluate the sustainability of projects during the conceptual stage. Nguyen et al. (2015) proposed the LEED green building assessment criteria framework to be included in BIM to possess an automated tool for the green rating. Wong and Kuan (2014) created the BIM-BEAM plus green assessment and the BIMintegration system in Hong Kong.

\subsection{Discussions and insights for effective adoption of BIM for sustainability}

It is commonly known that construction outputs, such as buildings, consume a considerably higher proportion of energy and not to mention the effect of the economy and social impacts

on the built environment. In the United States, for example, buildings consume approximately $40 \%$ of entire energy consumption and release $30 \%$ of greenhouse gases into the atmosphere every year (UNEP SBCI, 2009). In this regard, the need for sustainable 
buildings to lessen impacts of global warming is rising. By referring to the results of the review, some important insights have been drawn to optimise the effective adoption of BIM for sustainability.

\subsection{BIM adoption for standard sustainability assessment}

By reviewing the BIM standards and guidelines, it can be concluded that they stipulate the methodologies of BIM adoption and how project participants can coordinate the model and work in a collaborative environment that contributes to the improvement of social sustainability. However, the result of the review revealed that not every standard or guideline required BIM output to fit into the standard green assessment system. It is essential to incorporate the green assessment criteria into BIM standards and guidelines as they deal with site selection during the planning stage, green building materials selection during the design stage, energy efficiency use during the operation phase, and air ventilation during the maintenance phase, which is needed to improve built-environment sustainability (Aspinall et al., 2012). Yahya et al. (2016) also urged that future work must examine the way that ecoindicators can be included in projects via strategies of BIM implementation. The inclusion of green assessment criteria in BIM standards and guidelines could compel designers, contractors, researchers, and BIM vendors to establish a BIM profile that matches the sustainability requirements.

\subsection{Establishment of the Innovative Procurement System}

To achieve social sustainability, an entire project procurement strategy has to be created because the current practices involved with BIM do not fit into the fragmented nature of 
conventional project delivery of construction projects. In a BIM working environment, building design, construction techniques, information sharing, facilities-management strategy, and a more multidisciplinary collaboration effort are required (Sebastian, 2011). Although BIM standards and guidelines outline the responsibility of each stakeholder in dealing with BIM use, the collaboration issues remain as the existing contracts hinder the integration of downstream stakeholders' knowledge contribution in the early design stage. Apparently, the existing contract strategies do not fit into the characteristics of BIM. Some recent studies have begun to look into the integrative approach to address this social sustainability issue. Integrated Project Delivery (IPD) has been found to be an innovative project delivery system that integrates all resources used in the project life cycle (Wong and Fan, 2013). In its current state, the construction industry still prefers to adopt a conventional procurement approach (Chew and Riley, 2013) because of the fear of additional risk and liabilities arising from a new procurement system. Empirical research is required to study the best practice to deliver BIM to achieve better social sustainability.

4.3 The BIM uses of demolition and aspects of refurbishment have to be streamlined

There were not many standards and guidelines addressed in the BIM uses of demolition and aspects of refurbishment. Reuse of recycle materials and green construction methods are imperative to improving sustainability in the built environment. Cheng and Ma (2012) asserted that an advantage of BIM is that it can provide a quick and accurate estimation of waste materials in demolition projects. When generating a model for demolition works, the critical issue always faced by practitioners and clients is a lack of accurate information about existing buildings. During the construction phase, the existing drawings may have been changed or not followed, which resulted in many practitioners creating a dissimilar model 
with newly constructed works. The model of new work is generated directly from the ideas provided by the clients, whereas that of demolition works involve on-site verification of existing buildings, and it may rely on 2D drawings to produce a more reliable $3 \mathrm{D}$ model. The ways of handling materials, such as disposal and reuse, are varied in these fields (Galic et al., 2015). The requirements of having BIM in the retrofit and demolition phase, and the sustainable practice or methods of using BIM in demolition or deconstruction works, must be specified and streamlined in the BIM standards or guidelines to promote the sustainability efforts.

4.4 The need for an improved interoperability among BIM software and energy-simulation tools

The result of a review also showed that substantial efforts were carried out to integrate BIM with energy-simulation tools. Conventional practice requires design data to be inserted manually into building energy model (BEM) analysis. This could result in the possibility of missing materials data (Bazjanac and Kiviniemi, 2007). The design data should be exchanged between BIM and the energy-simulation tool using data transfer schemas such as the Industry Foundation Classes (IFC) and Extensible Markup Language (XML). However, the issue occurs that there is a lack of energy domain in open-data schemas (Cemesova et al., 2015). If an integrated energy modelling is created, the interoperability issue between BIM and energysimulation software has to be resolved (Gourlis and Kovacic, 2016). More empirical study is required to establish the application of open-data standards to conceptual facility design for energy, thermal comfort, and daylighting (GSA, 2015).

\subsection{Conclusions}


The proposed mixed review has determined BIM's current state-of-the-art development for sustainability based on the identified thirty-six (36) up-to-date BIM guidelines or standards and ninety-one (91) academic publications. The results show that the BIM standards and guidelines are mainly focused on the categories of planning, design, construction, energy consumption, operation and maintenance; whereas the academic publications have revealed a strong and growing interest on the categories of design and energy consumption.

Several noteworthy theoretical and practical implications have been uncovered based on the current research gap and status of development. To the theoretical aspects, new BIM tools need to be developed for assessing related sustainability criteria throughout the project's life cycle, including the materials used and energy-consumption aspects. On the one hand, an innovative procurement system needs to be formulated to adapt the social sustainability in the project. On the other hand, practical implications need to streamline the BIM uses into the aspects of demolition and refurbishment, and also to improve the interoperability issue among BIM software and energy-simulation tools. Ultimately, a unified approach is required by integrating BIM technologies with all sustainability aspects.

Future policies of BIM for sustainability should consider and adopt the abovementioned implications. For instance, the new or revised BIM standards and guidelines should include a set of requirements on the BIM tools to comply with a standard sustainability assessment. The assessment should make clear the specifications of building materials and energy modelling used in the project. Some specifications include material properties calculation, carbon estimation, hazardous substances evaluation, and material sustainability assessment. The energy modelling should provide the criteria for sun controls, 
natural ventilation, daylighting, and other energy simulations. In terms of the social sustainability aspect, BIM standards and guidelines should include elements of relational contracting in the project delivery system, especially for public involvement and other downstream project stakeholders. The BIM uses in refurbishment and demolition aspects should impose certain restrictions of waste management and reinstatement policies for the subsequent refurbished or demolished works. IFC standards should also be extended and clearly defined in the BIM standards or guidelines to enhance the BIM uses in various energy analysis.

\section{Acknowledgements}

The authors would like express our gratitude to the anonymous reviewers for their constructive comments and enlightening suggestions in improving an earlier version of this manuscript.

\section{References}

Anton, L.A., Diaz, J., 2014. Integration of lifecycle assessment in a BIM environment. Procedia Eng. 85, 26 - 32. DOI:10.1016/j.proeng.2014.10.525

Abanda, F. H., Byers, L., 2016. An investigation of the impact of building orientation on energy consumption in a domestic building using emerging BIM (Building Information Modelling). Energy. 97, 517-527. DOI:10.1016/j.energy.2015.12.135

ACIF APCC, 2014. A Framework for the Adoption of Project Team Integration and Building Information Modelling. Australian Industry Construction Forum \& Australian Procurement \& Construction Council, Canberra, Australia. 
Adeyemi,A., Martin, D., Kazim, R., 2014. Elimination of Waste and Inefficient Facilities in Existing Buildings for Sustainability in Developing Nations. Int. J. of Archit. and Urban Dev. 4(1), 5-16.

AEC UK, 2015. AEC (UK ) BIM Protocol, London, UK.

AFCEE, 2011. “ATTACHMENT F”- BIM Requirement, United States Air Force Center for Engineering and the Environment, San Antonio, Lackland, USA.

AGC, 2013. The Contractor's Guide to BIM, Associated General Contractors of America, Virginia, USA.

Ahn, K. U., Kim, Y. J., Park, C. S., Kim, I., Lee, K., 2014. BIM interface for full vs. semiautomated building energy simulation. Energy \& Build. 68, 671-678. DOI:10.1016/j.enbuild.2013.08.063

AIA, 2013. Guide, Instructions and Commentary to the 2013 AIA Digital Practice Documents, American Institute of Architects, Washington, USA.

Ajayi,S.O., Oyedele, L.O., Ceranic,B., Gallanagh,M., Kadiri,K.O., 2015. Life cycle environmental performance of material specification: a BIM-enhanced comparative assessment. Int. J. of Sustainable Build. Technol. \& Urban Dev. 6(1), 14-24. DOI: 10.1080/2093761X.2015.1006708

Akinadea,O.O., Oyedelea,L.O., Bilala,M., Ajayia,S.O., Owolabia, H.A., Alakaa, H.A., Bellob,S.A., 2015. Waste minimisation through deconstruction: A BIM-based Deconstructability Assessment Score (BIM-DAS). Resour., Conserv. \& Recycl. 105,167-176. DOI:10.1016/j.resconrec.2015.10.018

Al-Ghamdi, S.G., Bilec, M.M., 2015. Life-Cycle Thinking and the LEED Rating System: Global Perspective on Building Energy Use and Environmental Impacts. Environ. Sci. \& Technol. 49, 4048-4056. DOI: 10.1021/es505938u 
Almahmoud, E., Doloi, H.K., 2015. Assessment of social sustainability in construction projects using social network analysis. Facilities. 33(3/4), 152-176.

Alwan , Z., Greenwood, D., Gledson ,B., 2015. Rapid LEED evaluation performed with BIM-based sustainability analysis on a virtual construction project, Constr. Innov. 15 (2), 134 - 150. DOI:10.1108/CI-01-2014-0002

AMCA, 2011. BIM-MEPAUS Practice, Mechanical Contractors' Association, Victoria, Australia.

AOES, 2015. BIM Guidelines \& Standards for Architects, Engineers, and Contractors, Indiana University Architect's Office and Engineering Services, Victoria, USA.

Arayici, Y., Coates,P., Koskela,L., Kagioglou,M. , Usher,C. O'Reilly,K., 2011. Technology adoption in the BIM implementation for lean architectural practice. Auto. in Constr. 20, 189-195. DOI:10.1016/j.autcon.2010.09.016.

Arthur, J.J., 2015.A building information management (BIM) framework and supporting case study for existing building operations, maintenance and sustainability. Procedia Eng. 118, 1104 - 1111. DOI: 10.1016/j.proeng.2015.08.450.

Asl,M.R., Zarrinmehr, S., Bergin,M. , Yan,W., 2015. BPOpt: A framework for BIM-based performance optimization. Energy and Buildings. 108, 401-412. DOI:10.1016/j.enbuild.2015.09.011

Aspinall,S., Sertyesilisik, B, Sourani,A., Tunstall, A., 2012. How Accurately Does BREEAM Measure Sustainability? Creat. Educ. 3:1-8. DOI:10.4236/ce.2012.37B001

Azapagic, A., Perdan, S., 2014. Sustainable chemical engineering: dealing with wicked sustainability problems. AIChE J. 60 (12), 3998-4007. DOI: 10.1002/aic.14650.

Azhar, S., Carlton, W.A.,Olsen,D., Ahmad, I., 2011. Building information modeling for sustainable design and LEED® rating analysis. Auto. in Constr., 20 (2), 217-224. DOI:10.1016/j.autcon.2010.09.019 
Barazzetti,L., Banfi,F., Brumana,R., Gusmeroli,G., Previtali,M., 2015.Cloud-to-BIM-toFEM: Structural simulation with accurate historic BIM from laser scans. Simul. Model. Pract. \& Theory. 57 , 71-87. DOI: 10.1016/j.simpat.2015.06.004

Basbagill,J. Flager,F., Lepech, M., Fischer,M., 2013. Application of life-cycle assessment to early stage building design for reduced embodied environmental impacts. Build. \& Environ. 60,81-92.DOI:10.1016/j.buildenv.2012.11.009

Bazjanac,V., Kiviniemi, A., 2007. Reduction, simplification, translation and interpretation in the exchange of model data. Proc. of the 24th CIB W78 Conf.: Bringing ICT knowledge to work. 163-168. University of Maribor, Maribor.

BCA, 2013. Singapore BIM Guide, Building and Construction Authority: Singapore.

Bonenberg,W., Xia, W., 2015. Green BIM in sustainable infrastructure. Procedia Manuf.. 3: 1654 - 1659. DOI:10.1016/j.promfg.2015.07.483

Bosché,F., Ahmed,M., Turkan,Y., Haas,C.T., Haas,R., 2015. The value of integrating Scanto-BIM and Scan-vs-BIM techniques for construction monitoring using laser scanning and BIM: The case of cylindrical MEP components. Auto. in Constr. 49, 201213.DOI:10.1016/j.autcon.2014.05.014

Bryde, D., Broquetas, M., Volm, J.M., 2013. The project benefits of Building Information Modelling (BIM). Int. J. of Proj. Manag. 31(7), 971-980. DOI:10.1016/j.ijproman.2012.12.001

BuildingSMART Finland, 2012. Common BIM Requirements 2012, buildingSMART Finland, Helsinki, Finland. Cao, D.P.,

Wang, G.B., Li, H., Skitmore, M., Huang, T., Zhang, W.Y., 2015. Practices and effectiveness of building information modelling in construction projects in China. Auto. in Constr. 49 ,113-122. DOI: 10.1016/j.autcon.2014.10.014 
Ceranic, D.B., Lathamb,D. , Dean, A., 2015. Sustainable Design and Building Information Modelling: Case Study of Energy Plus House, Hieron's Wood, Derbyshire UK. Energy Procedia. 83, 434-443. DOI: 10.1016/j.egypro.2015.12.163

Cemesova, A., Hopfe, c. J. ,Robert S.M., 2015. Auto. in Constr., 57, 17-32. DOI: 10.1016/j.autcon.2015.04.014

Chen, Y.T., Chang, D.S., Chen, C.Y., Chen, C.C., 2012. The policy impact on clean technology diffusion. Clean Technol. \& Environ. Policy, 14,699-708 DOI 10.1007/s10098-011-0435-4.

Cheng, J., Ma, L., 2013. A BIM-based system for demolition and renovation waste quantification and planning. Waste Manag. 33(6), 1539-1551. hdl.handle.net/1783.1/58041. (Accessed 03.03.16)

Cheng,C.P., Das,M., 2014. A Bim-based Green Service Framework for Building Energy Simulationn and Code Checking. J. of Inf. Technol. in Constr., 19:150-168. itcon.org/2014/8 (accessed 23.04.16)

Chiang,C.T., Chu,C.P., Chou,C.C., 2015. BIM-enabled Power Consumption Data Management Platform for Rendering and Analysis of Energy Usage Patterns. Procedia Eng. 18, 554-562. DOI:10.1016/j.proeng.2015.08.480

Cho,C.S., Chen,D., Woo,S.K., 2012. Building Information Modeling (BIM)-Based Design of Energy Efficient Buildings. J. of Korean Inst. of Build. Inf. Model., 2 (1).1-6.

Chong, H. Y., \& Wang, X., 2016. The outlook of building information modeling for sustainable development. Clean Technol. \& Environ. Policy, 1-11. (DOI 10.1007/s10098-016-1170-7)

Chong, H. Y., Wang, J., Shou, W., Wang, X., Guo, J., 2014. Improving Quality and Performance of Facility Management Using Building Information Modelling. 
Cooperative Des. , Visualization, \& Eng. 8683,44-50. DOI:10.1007/978-3-319-108315_6

CIC, 2013. Best Practice Guide for Professional Indemnity Insurance when using BIM and, Outline Scope of Services, Construction Industry Council, London, UK.

Ciribini, A.L.C., Bolpagni, M., Oliveri, E., 2015. An Innovative Approach to e-public Tendering Based on Model Checking. Procedia Econ. \& Financ. 21, 32-39. DOI: $10.1016 / \mathrm{S} 2212-5671(15) 00147-1$.

CoD , 2011. BIM GUIDE, College of the Desert, Palm Desert, USA.

COSA, 2011. Building Information Modelling (BIM) Development Criteria and Standards for Design \& Construction Projects. COSA BIM Standards. City of San Antonio, City of San Antonio, San Antonio, Texas.

Costa, A.A., Grilo, A., 2015. BIM-Based E-Procurement: An Innovative Approach to Construction E-Procurement. The Scientific World J. DOI:10.1155/2015/905390

Costa,G., Madrazo, L., 2015. Connecting building component catalogues with BIM models using semantic technologies: an application for precast concrete components. Auto. in Constr. 57, 239-248. DOI:10.1016/j.autcon.2015.05.007

CPEC, 2012. MIT CAD \& BIM Guidelines, MIT Campus Planning, Engineering, and Construction, Boston, USA.

CPO, 2012. Attachment G - University of Washington CAD and BIM Standards, University of Washington Capital Projects Office, Seattle, USA.

DOA/DSF, 2012. BIM Guidelines \& Standards for ARCHITECTS and ENGINEERS Department of Administration, Division of State Facilities, Wisconsin, USA

Eastaway, M.P.,2012. Social sustainability, in: Smith, S., Lowell, H., Pareja-Eastaway, M. (Eds.), Encyclopaedia of Housing and Home Woodstock.Elsevier, USA, pp.501-505. 
Eastman, C., Teicholz, P., Sacks, R., Liston, K., 2011. BIM handbook: A guide to building information modeling for owners, managers, designers, engineers and contractors. John Wiley \& Sons, New York, United States of America.

Elmualim, A., Gilder, J., 2014. BIM: innovation in design management, influence and challenges of implementation. Archit. Eng. \& Design Manag.10(3-4), 183-199. DOI: $10.1080 / 17452007.2013 .821399$.

European Directive, 2010. 2010/31/EU of the European Parliament and of the Council of 19 May 2010 on the energy performance of buildings (recast).

FMS, 2012. BIM Guidelines, University of Southern California Facilities Management Services, Los Angeles, USA.

Francom,T.C., Asmar,M.E., 2015. Project Quality and Change Performance Differences Associated with the Use of Building Information Modeling in Design and Construction Projects: Univariate and Multivariate Analyses. J. of Constr. Eng. \& Manag., 141(9). 04015028. DOI: 10.1061/(ASCE)CO.1943-7862.0000992

Galic, M., Alduk, Z.D., Cerovecki, A., Glick,D. , Abramovie,M., 2015. BIM in planning deconstruction projects. eWork \& eBusiness in Archit., Eng. \& Const. 81-85.

Geyer, P., 2012. Systems modelling for sustainable building design. Adv. Eng. Informatics. 26(4), 656-668. DOI:10.1016/j.aei.2012.04.005

Gibbs, D. J., Emmitt, S., Lord, W., Ruikar, K., 2015. BIM and Construction Contracts: CPC 2013's approach. Proc. of the ICE-Manag., Procure. \& Law. In press. DOI: 10.1680/jmapl.14.00045

Gibbs, D., O’Neill, K., 2014. The green economy, sustainability and transition regions: A case study of Boston. In Geografiska Annaler: Series B, Human Geography, Swedish Society for Anthropology and Geography, Sweden, 96(3), 201-216. 
Gourlis, G. and Kovacic, I., 2016. Building Information Modelling for analysis of energy efficient industrial buildings-A case study. Renewable and Sustainable Energy Reviews. DOI: $10.1016 /$ j.rser.2016.02.009

Grilo, A. Goncalves, R.J., 2011. Challenging electronic procurement in the AEC sector: A BIM-based integrated perspective. Auto. in Constr. 20, 107114.DOI:10.1016/j.autcon.2010.09.008.

GSA, 2015. National 3D-4D BIM Program, United States General Services Administration, Washington, USA.

GSFIC, 2013. BIM Guide, Georgia State Financing and Investment Commission, Georgia, USA.

GTFM, 2016. Georgia Tech BIM Requirements \& Guidelines for Architects, Engineers and Contractors, Georgia Tech Facilities Management, Georgia, USA.

Guo, S.J. , Wei, T., 2016. Cost-Effective Energy Saving Measures Based on BIM Technology: Case Study at National Taiwan University. Energy \& Build..127,433-441.

Hajibabai,1., Aziz, Z., Peña-Mora, F., 2011. Visualizing greenhouse gas emissions from construction activities. Constr. Innov., 11(3), 356- $370 . \quad$ DOI: $10.1108 / 14714171111149052$

HKCIC, 2015. CIC Building Information Modelling Standards (Phase One). Construction Industry Council, Wanchai, Hong Kong.

Ho, S., Rajabifard, A., 2016. Towards 3D-enabled urban land administration: Strategic lessons from the bim initiative in singapore. Land Use Policy. 57, 1-10.DOI: 10.1016/j.landusepol.2016.05.011

HolmströM, j., Singh,v., Främling, K., 2015. BIM as Infrastructure in a Finnish HVAC Actor Network: Enabling Adoption, Reuse, and Recombination over a Building Life Cycle 
and between Projects. J. of Manag. \& Eng. 31(1), A4014006.DOI: 10.1061/(ASCE)ME.1943-5479.0000305.

Hou, L., Wang, X.Y., Truijens, M., 2015.Using Augmented Reality to Facilitate Piping Assembly: An Experiment-Based Evaluation. J. of Comput. in Civ. Eng., 29(1): 05014007. DOI: 10.1061/(ASCE)CP.1943-5487.0000344

Ilhan, B. ,Yaman, H., 2016. Green building assessment tool (GBAT) for integrated BIM-based design decisions. Auto. in Constr. DOI:10.1016/j.autcon.2016.05.001

Inyim, P., Rivera, J., Zhu.Y.M., 2015. Integration of Building Information Modeling and Economic and Environmental Impact Analysis to Support Sustainable Building Design. J. of Manag. in Eng., 31(1): A4014002. DOI: 10.1061/ (ASCE)ME.1943-5479.0000308 Irizarry,J., Karan,E.P., Jalaei,F.,2013. Integrating BIM and GIS to improve the visual monitoring of construction supply chain management. Auto. in Constr. 31, 241-254. DOI:10.1016/j.autcon.2012.12.005

ISO 14040, 2006. Environmental management-Life cycle assessment-Principles and framework. International Organization for Standardization, Geneva, Switzerland.

IU, 2015. BIM Guidelines \& Standards for Architects, Engineers, and Contractors. Indiana University, Indiana, United States.

Jalaei,F., Jrade, A., 2014. An Automated BIM Model to Conceptually Design, Analyze, Simulate, and Assess Sustainable Building Projects. J. of Constr. Eng. 672896, 21 pages. DOI:10.1155/2014/672896

Jalaei,F., Jrade,A., 2015. Integrating building information modeling (BIM) and LEED system at the conceptual design stage of sustainable buildings. Sustainable Cities \& Society 18 , 95-107. DOI:10.1016/j.scs.2015.06.007 
Jones,B., 2014. Integrated project delivery (IPD) for maximizing design and construction considerations regarding sustainability. Procedia Eng. 95, 528- 538. DOI: 10.1016/j.proeng.2014.12.214.

Jrade,A.,Jalaei,F., 2013. Integrating building information modelling with sustainability to design building projects at the conceptual stage. Archit. \& Human Behavior Build. Simul. 6(4), 429-444. DOI: 10.1007/s12273-013-0120-0

Jung,J.h., Hong,s.c., Yoon,S.H., Kim,J.H., Heo, J., 2015. Automated 3D Wireframe Modeling of Indoor Structures from Point Clouds Using Constrained Least-Squares Adjustment for As-Built BIM. J. of Comput. in Civ. Eng., 04015074-1-15.DOI: 10.1061/(ASCE)CP.1943-5487.0000556

Kapogiannisa, G., Gaterellb,M., Oulasoglou. E., 2015. Identifying uncertainties toward sustainable projects. Procedia Eng. 118, 1077-1085. DOI:10.1016/j.proeng.2015.08.551.

Karan,E.P., Irizarry, J., 2015.Extending BIM interoperability to preconstruction operations using geospatial analyses and semantic web services. Auto. in Constr. 53,1-12. DOI:10.1016/j.autcon.2015.02.012.

Khaddaj, M. and Srour, I., 2016. Using BIM to Retrofit Existing Buildings. Procedia Eng..145, 1526-1533. DOI: 10.1016/j.proeng.2016.04.192

Khan, E.a., Dewan, M.N.A., Chowdhery, M.M.H., 2016. Reflective or formative measurement model of sustainability factor? A three industry comparison. Corporate Ownership and Control. 13(2), 83-92.

Kim,H.J., Anderson, K., 2013. Energy Modeling System Using Building Information Modeling Open Standards. J. of Comp. in Civ. Eng. DOI: 10.1061/(ASCE)CP.19435487.0000215. 
Kim, M. K., Cheng, J. C., Sohn, H., Chang, C. C. , 2015. A framework for dimensional and surface quality assessment of precast concrete elements using BIM and 3D laser scanning. Auto. in Constr., 49, 225-238. DOI:10.1016/j.autcon.2014.07.010

Kim, J.I., Koo,B.S., Suh, S.D., Suh, W.H. , 2015a. Integration of BIM and GIS for Formal Representation of Walkability for Safe Routes to School Programs. J. of Civ. Eng., 17.DOI 10.1007/s12205-015-0791-4

Kim,J.B., Jeong,W.S., Clayton,M.J., Haberl,J.S., Yan,W., 2015b. Developing a physical BIM library for building thermal energy simulation. Auto. in Constr. 50, 16-28. DOI:10.1016/j.autcon.2014.10.011.

Kim,J.I., Kim,J.H., Fischer,M., Orr,R., 2015c. BIM-based decision-support method for master planning of sustainable large-scale developments. Auto. in Constr. 58, 95-108. DOI:10.1016/j.autcon.2015.07.003

Kim, S., Zadeh, P.A., Staub-French, S., Froese, T. and Cavka, B.T., 2016. Assessment of the Impact of Window Size, Position and Orientation on Building Energy Load Using BIM. Procedia Eng. 145, 1424-1431. DOI: 10.1016/j.proeng.2016.04.179

Korkmaz, s.m., Swarup, 1., Riley, D., 2013. Delivering Sustainable, High-Performance Buildings: Influence of Project Delivery Methods on Integration and Project Outcomes. J. of Manag. in Eng. 29(1),71-78.DOI: 10.1061/(ASCE)ME.1943- 5479.0000114.

Kovacic, I., Waltenbereger, L., Gourlis, G., 2015. Tool for life cycle analysis of facade-systems for industrial buildings. J. of Clean. Prod. 1-13. DOI: 10.1016/j.jclepro.2015.10.063

Kumar,S.S., Cheng, J.C.P., 2015. A BIM-based automated site layout planning framework for congested construction sites. Auto. in Constr. 59, 2437.DOI:10.1016/j.autcon.2015.07.008.

Kylili,A., Fokaides,P.A., Vaiciunas,J., Seduikyte, L., 2015. Integration of Building Information Modelling (BIM) and Life Cycle Assessment (LCA) for sustainable 
constructions. J. of Sustain. Archit. \& Civ. Eng. 4(13), 28-38.DOI 10.5755/j01.sace.13.4.12862

LACCD, 2016. BIM Standard. Los Angeles Community College District, Los Angeles, USA. Lee, S.W., Tae, S.H., Roh, S.J., Kim, T.H., 2015. Green Template for Life Cycle Assessment of Buildings Based on Building Information Modeling: Focus on Embodied Environmental Impact. Sustainability. 7,16498-16512. DOI:10.3390/su71215830

Lin,Y.C., 2014. Construction 3D BIM-based knowledge management system: a case study. J. of Civ. Eng.\& Manag. 20(2), 186-200. DOI: 10.3846/13923730.2013.801887

Liu,S., Meng, X.H., Tam,C.M., 2015. Building information modeling based building design optimization for sustainability. Energy \& Build., 105: 139-153. DOI:10.1016/j.enbuild.2015.06.037

Lu, W., Fung, A., Peng, Y., Liang, C. ,Rowlinson, S., 2014. Cost-benefit analysis of Building Information Modelling implementation in building projects through demystification of time-effort distribution curves. Build. \& Environ. 82, 317-327.

MacLeamy, 2004. Construction Users Roundtable's “Collaboration, Integrated Information, and the Project Lifecycle in Building Design and Construction and Operation” (WP-1202, August, 2004)”. msa-ipd.com/MacleamyCurve.pdf. (accessed 05.03.16)

Maia,L., Mêdab,P., Freitasa, J.G., 2015. BIM methodology, a new approach - case study of structural elements creation. Procedia Eng. 114, 816-823. DOI: 10.1016/j.proeng.2015.08.032

Matthews, J.,Love, P. , Heinemann, S. , Chandler, R., Rumsey, C., Olatunj, O. , 2015. Real time progress management: Re-engineering processes for cloud-based BIM in construction. Auto. in Constr. 58, 38-47. DOI:10.1016/j.autcon.2015.07.004 
McGuire, B., Atadero,R., Clevenger,C. ,Ozbek,M., 2016. Bridge Information Modeling for Inspection and Evaluation. J. of Bridge Eng., 04015076.DOI: 10.1061/ (ASCE) BE.1943-5592.0000850.

Means, P.,Guggemos, A., 2015. Framework for Life Cycle Assessment (LCA) based environmental decision making during the conceptual design phase for commercial buildings. Procedia Eng. 118 , 802 -812. DOI: 10.1016/j.proeng.2015.08.517

MIKR, 2012. Rgd BIM Standard, Rijksgebouwendienst (Ministry of the Interior and Kingdom Relations), The Netherlands.

Motawa, I., Carter,K., 2013. Sustainable BIM-based Evaluation of Buildings. Procedia Social \& Behavioral Sci. 74,419-428.DOI:10.1016/j.sbspro.2013.03.015

Mousa, M., Luo, X. and McCabe, B., 2016. Utilizing BIM and Carbon Estimating Methods for Meaningful Data Representation. Procedia Eng. 145, 1242-1249. DOI: 10.1016/j.proeng.2016.04.160

NATSPEC, 2016. NATSPEC National BIM Guide. NATSPEC Construction Information, Sydney, Australia.

Nawari,O.N., 2012. BIM Standard in Off-Site Construction. J. of Archit. Eng. 18(2),107-113. DOI: 10.1061/(ASCE)AE.1943-5568.0000056

Nguyen, T., Toroghi, S., Jacobs, F., 2015. Automated Green Building Rating System for Building Designs. J. of Archit. Eng. DOI:10.1061/(ASCE)AE.1943-5568.0000168

Ness, D., Swift, J., Ranasinghe, D.C., Xing, K. , Soebarto, V., 2015. Smart steel: new paradigms for the reuse of steel enabled by digital tracking and modelling. J. of Clean. Prod. 98, 292-303.DOI: 10.1016/j.jclepro.2014.08.055

NHBA, 2012. BoligBIM (BIM Manual), Boligprodusentene (Norwegian Home Builders Association), Oslo, Norway.

NIBS, 2015. National BIM Standard-United States ${ }^{\circledR}$ (NBIMS-US ${ }^{\mathrm{TM}}$ ) Version 3, Washington, USA. 
Niknam,M., Karshenasb, S. ,2015. Sustainable Design of Buildings using Semantic BIM and Semantic Web Services. Procedia Eng., 118, 909- 917.DOI: 10.1016/j.proeng.2015.08.530.

Niu,S., Pan,W., Zhao, Y., 2015. A BIM-GIS Integrated Web-based Visualization System for Low Energy Building Design. Procedia Eng., 121,2184- 2192. DOI: 10.1016/j.proeng.2015.09.091

NYCDDC, 2012. BIM Guidelines. Department Design and Construction, New York, United States.

NYCSCA, 2014. BIM Guidelines and Standards for Architects and Engineers, New York City School Construction Authority, New York, USA.

OFCC, 2012.BIM Protocol, State of Ohio Facilities Construction Commission, Ohio, USA.

Oti, A., Tizani, W., Zada, A., 2014.A BIM Extension for Sustainability Appraisal of Conceptual Structural Design of Steel-Framed Buildings. Comput. in Civ. \& Build. Eng. 219-226. DOI 10.1061/9780784413616.028

Oti, A.H., Tizani, W., Abanda, F.H., Jaly-Zada, A. and Tah, J.H.M., 2016. Structural sustainability appraisal in BIM. Auto. in Constr. 69, 44-58.DOI: 10.1016/j.autcon.2016.05.019

Pawson, R., Greenhalgh, T., Harvey, G., Walshe, K., 2005. Realist review - a new method of systematic review designed for complex policy interventions. J. of Health Services Research \& Policy. 10(1): 21 - 34.DOI: 10.1258/1355819054308530

Peng, C., 2016. Calculation of a building's life cycle carbon emissions based on Ecotect and building information modeling. J. of Clean. Prod., 112,453-465.DOI: 10.1016/j.jclepro.2015.08.078 
Plebankiewicz, E., Zima, K. ,Skibniewski, M., 2015. Analysis of the first Polish BIM-Based cost estimation application. Procedia Eng. 123, 405-414.DOI: 10.1016/j.proeng.2015.10.064

Porwal A. ,Hewage K.N., 2013. Building Information Modeling (BIM) Partnering Framework for Public Infrastructure Projects. Auto. in Constr. 138, 943-954. DOI:10.1016/j.autcon.2012.12.004

Porwal, A. , Hewage, K.N., 2012. Building Information Modeling-Based Analysis to Minimize Waste Rate of Structural Reinforcement. J. of Constr. in Eng. \& Manag., 138(8): 943-954. DOI: 10.1061/(ASCE)CO.1943-7862.0000508

PSU, 2013. BIM Planning Guide for Facility Owners, The Pennsylvania State University, Pennsylvania, USA.

Ren, Y., Skibniewski, M., Jiang, S.H., 2012. Building information modeling integrated with electronic commerce material procurement and supplier performance management system. J. of Civ. Eng. \& Manag. 18(5),642-654. DOI: 10.3846/13923730.2012.719835

Ryu, H.S., Park, K.S., 2016. A Study on the LEED Energy Simulation Process Using BIM. Sustainability. 8,138. DOI: 10.3390/su8020138.

Said,H., 2016. Modeling and Likelihood Prediction of Prefabrication Feasibility for Electrical Construction Firms. J. of Constr. in Eng. \& Manag.. 142(2), 04015071. DOI: 10.1061/(ASCE)CO.1943-7862.0001051.

Sassi, P., 2016. Built Environment Sustainability and Quality of Life (BESQoL) Assessment Methodology, in W. Leal Filho, L. Brandli (eds.) Engaging Stakeholders in Education for Sustainable Development at University Level, World Sustainability Series. Springer International Publishing Switzerland, UK. DOI 10.1007/978-3-319-26734-0_2 
SBEnrc, 2015.National BIM Guidelines and Case Studies for Infrastructure. SBEnrc: Australia.

SDCCD, 2012. BIM Standards for Architects, Engineers \& Contractors, San Diego Community College District, San Diego, USA.

Sebastian, R, 2011. Changing roles of the clients, architects and contractors through BIM. Eng., Constr. \& Archit. Manag., 18,176 - 187. DOI: 10.1108/09699981111111148

SEC, 2013. First Steps to BIM Competence: A Guide for Specialist Contractors, Specialist Engineering Contractors' Group and BIM Academy at the University of Northumbria, Northumbria, UK.

Shafiq,N., Nurrudin,M.F., Gardezi, S.S.S. ,Kamaruzzaman, A., 2015. Carbon footprint assessment of a typical low rise office building in Malaysia using building information modelling (BIM). Int. J.of Sustainable Build. Technol. \& Urban Dev. DOI: 10.1080/2093761X.2015.1057876

Shen,X., Marks,E. (2015). Near-Miss Information Visualization Tool in BIM for Construction Safety. J. of Constr. in Eng. \& Manag. DOI: 10.1061/(ASCE)CO.19437862

Shi, Y., Du, J., Lavy, S. and Zhao, D., 2016. A Multiuser Shared Virtual Environment for Facility Management. Procedia Eng. 145, 120-127.DOI: 10.1016/j.proeng.2016.04.029

Shin, Y.S., Cho, K.M., 2015. BIM Application to Select Appropriate Design Alternative with Consideration of LCA and LCCA. Mathematical Problems in Eng., 281640. DOI: $10.1155 / 2015 / 281640$

Singh, V., Gu, N., Wang, X., 2011. A theoretical framework of a BIM-based multidisciplinary collaboration platform. Auto. in Constr.. 20(2), 134-144. DOI:10.1016/j.autcon.2010.09.011 
Smith, P., 2014. BIM \& the 5D Project Cost Manager. Procedia - Social \& Behavioral Sci. 119,475 -484. DOI: 10.1016/j.sbspro.2014.03.053

Statsbygg, 2013. Statsbygg BIM Manual, Statsbygg, Oslo, Norway.

Swarup, L., Korkmaz,S. , Riley, D., 2011. Project Delivery Metrics for Sustainable, HighPerformance Buildings. J. of Const. Eng. \& Manag., 137(12): 1043-1051. DOI: 10.1061/(ASCE)CO.1943-7862.0000379.

Tahmasebi, M.M., Banihashemi, S., Hassanabadi,M.S., 2011. Assessment of the Variation Impacts of Window on Energy Consumption and Carbon Footprint. Procedia Eng., 21, 820-828. DOI:10.1016/j.proeng.2011.11.2083

TPA, 2015. E/A Design Division BIM Standard. The Port Authority of NY \& NJ Engineering Department, New York, United States.

TFC, 2010. Professional Service Provider Guidelines and Standards, Texas Facilities Commission, Texas, USA.

UNEP SBCI, 2009. Buildings and Climate Change: Summary for Decision Makers. Sustainable United Nations, United Nations Environment Programme. Paris, France.

USACE, 2012. Roadmap for Life-Cycle BIM, United States Army Corps of Engineers, Washington DC, USA.

Wang, C. , Cho, Y.K., Kim, C.W. 2015. Automatic BIM component extraction from point clouds of existing buildings for sustainability applications. Auto. in Constr. 56, 1-13. DOI:10.1016/j.autcon.2015.04.001

Wang, C., Cho, Y., Kim, C. ,2015.Automatic BIM Component Extraction from Point Clouds of Existing Buildings for Sustainability Applications. Auto. in Constr., 56,1-13. DOI:10.1016/j.autcon.2015.04.001

Wang, X., Truijens, M., Hou, L., Wang, Y., Zhou, Y., 2014. Integrating Augmented Reality with Building Information Modeling: Onsite construction process controlling for 
liquefied natural gas industry. Auto. in Constr. 40,96-105. DOI:10.1016/j.autcon.2013.12.003

Wang, C. , Cho, Y.K. , 2015. Performance Evaluation of Automatically Generated BIM from Laser Scanner Data for Sustainability Analyses. Procedia Eng., 118, 918- 925. DOI: 10.1016/j.proeng.2015.08.531.

Wezet, E.M., Thabet, W.Y, 2015. The use of a BIM-based framework to support safe facility management processes. Auto. in Constr. 60:12-24.DOI: 10.1016/j.autcon.2015.09.004.

Wang, E., Shen, Z., 2013. A hybrid Data Quality Indicator and statistical method for improving uncertainty analysis in LCA of complex system-application to the whole-building embodied energy analysis. J. of Clean. Prod. 43, 166-173. DOI: 10.1016/j.jclepro.2012.12.010

Wong, J., Zhou, J., 2015. Enhancing environmental sustainability over building life cycles through green BIM: A review. Auto. in Constr., 156-165. DOI: 10.1016/j.autcon.2015.06.003.

Wong, K.W., Kuan, K.L., 2014. Implementing 'BEAM Plus' for BIM-based sustainability analysis. Auto. in Constr. 44,163-175. DOI:10.1016/j.autcon.2014.04.003.

Wu,W., Issa,R.R.A., 2015. BIM Execution Planning in Green Building Projects: LEED as a Use Case. J. of Manag. in Eng.,31(1),A4014007-1-18.DOI: 10.1061/(ASCE)ME.19435479.0000314

Xu., X., Ma, L., Ding, L.Y.,2014. A Framework for BIM-enabled Life-cycle Information Management of Construction Project. Int. J.of Advanced Robotic Systems. 11:126.DOI: $10.5772 / 58445$

Yahya, K., Boussabaine, H. and Alzaed, A.N., 2016. Using life cycle assessment for estimating environmental impacts and eco-costs from the metal waste in the construction industry. Manag. of Environ. Quality: An Int. J.27(2), 227-244. 
Yeheyis,M., Hewage,K., M.S., Alam, Eskicioglu,C. ,Sadiq,R., 2013. An overview of construction and demolition waste management in Canada: A lifecycle analysis approach to sustainability. Clean Technol. \& Environ. Policy. 15,81-91. DOI: $10.1007 / \mathrm{s} 10098-012-0481-6$

Yenumulaa,K., Kolmerb,C., Panc,J., Sub, X., 2015. BIM-Controlled Signage System for Building Evacuation. Procedia Eng. 118, 284- 289. DOI: 10.1016/j.proeng.2015.08.428.

Yun, S. H., Jun, K. H., Son, C. B., Kim, S. C., 2014.Preliminary study for performance analysis of BIM-based building construction simulation system. J. of Civ. Eng. 18(2), 531-540. DOI: 10.1007/s12205-014-0174-2

Yung, P., Wang, X.Y.,2014. A 6D CAD Model for the Automatic Assessment of Building Sustainability. Int. J. of Adv. Robotic Syst. 11:131.DOI: 10.5772/58446

Zhang, J., Long, Y., Lv, S. and Xiang, Y., 2016. BIM-enabled Modular and Industrialized Construction in China. Procedia Eng. 145, 1456-1461.DOI: 10.1016/j.proeng.2016.04.183

Zuo, J, Zhao, Z.Y. , 2014. Green building research-current status and future agenda: A review. Renewable and Sustainable Energy Reviews. 30, 271-281. DOI: 10.1016/j.rser.2013.10.021 